Abdalla Saad Abdalla Al-Zawi', Philip Idaewor', Amira Asaad', Rebeeca Harsten², Vanessa Salih ${ }^{3}$, Jessica English', Ali Salih', Marina Barron ${ }^{4}$, Peter Ozua ${ }^{5}$, Nazar Alsanjari ${ }^{5}$, Kingsley Osayi ${ }^{5}$, Samir Shah ${ }^{6}$

'Basildon and Thurrock University Hospital, Nethermayne, Basildon, Essex, United Kingdom

${ }^{2}$ King's College Hospital, London, United Kingdom

${ }^{3}$ Department of Surgery, Kings College Hospital, London, United Kingdom

${ }^{4}$ Royal Victoria Hospital, Belfast, United Kingdom

${ }^{5}$ Department of Pathomorphology, Basildon and Thurroch University Hospital, Nethermayne, Basildon, Essex, United Kingdom

${ }^{6}$ Department of Cardiothoracic Surgery, Basildon and Thurrock University Hospital, Nethermayne, Basildon, Essex, United Kingdom

\title{
Posterior Mediastinal Paravertebral Müllerian cyst (cyst of Hattori): literature review
}

\begin{abstract}
Mediastinal cysts are typically of bronchogenic, thymic or neurenteric origin, but may also represent oesophageal duplication. Posterior paravertebral mediastinal Müllerian cysts of undetermined pathogenesis are very rare occurrences. The first case of a ciliated cyst arising in the mediastinum, of probable Müllerian origin, was reported by Hattori in 2005, which gave rise to the name cyst of Hatorri $(\mathrm{COH})$ The number of reported cases in literature of a similar nature have since then increased significantly. One of the main concerns about this pathology is the possibility of malignant transformation of the Müllerian tissue. Over the course of this paper we will discuss the pathogenesis, immunohistochemistry and its role in differential diagnosis as well as optimal treatment of such cysts.
\end{abstract}

Key words: Mullerian cyst, cyst of Hattori, posterior mediastinum, paired box gene 8

Adv Respir Med. 2020; 88: 134-141

\section{Introduction}

The pathogenesis of Müllerian cysts, which are located in the posterior mediastinum, is not yet fully understood. It was suggested by Ludwig et al. in his study of Mayer-Rokitansky-Kuster-Hauser syndrome [1-3], that such cysts are possibly remnants of embryonic Müllerian tissue. The pathomorphology showed that the cysts were lined with ciliated columnar/tubal epithelium surrounded by a thin smooth muscular layer (Figure 1). The immunohistochemical profile demonstrated positivity to oestrogen as well as progesterone receptors. Such cysts, in relation to this condition, were first described by Hattori in 2005 as being female sex hormone receptor sensitive and situated in the posterior mediastinum [4].

\section{Pathogenesis}

In 1998, Ludwig reported that "in stage 16 embryos, a thickening of the coelomic epithe- lium develops on the cranial end of the plica mesonephrica at the level of the $3^{\text {rd }}$ to $5^{\text {th }}$ thoracic vertebral blastema and forms the anlage of the funnel area (of the fallopian tube)" [1]. There is a possibility that some of the rudimentary tissue lined by fallopian tubal epithelium persisted in the paravertebral mediastinal areas at T4-6 levels [5]. Accordingly, a Müllerian cyst could develop anywhere along the path of Müllerian duct regression [3, 6]. However, the origin of these cysts is still not fully understood. Firstly, mediastinal structures are not regarded as part of the secondary Müllerian system. Secondly, embryonic Müllerian structures have not been identified in the mediastinum, pleura or pericardium [7].

In 2010, a paper discussing the pathogenesis of cyst of Hattori by Batt et al. suggested that the cyst originated from the primary Müllerian tissue similar to the postulated pathogenesis of Mayer-Rokitansky-Kuster-Hauser syndrome (MRKH). This syndrome is characterized by the failure of the Müllerian duct to develop, resulting

Address for correspondence: Abdalla Saad Abdalla Al-Zawi, Basildon and Thurrock University Hospital, Nethermayne, Basildon, Essex, United Kingdom;

e-mail: abdalasaad@gmail.com

DOI: $10.5603 /$ ARM.2020.0089

Received: 17.02.2020

Copyright (C) 2020 PTChP

ISSN 2451-4934 


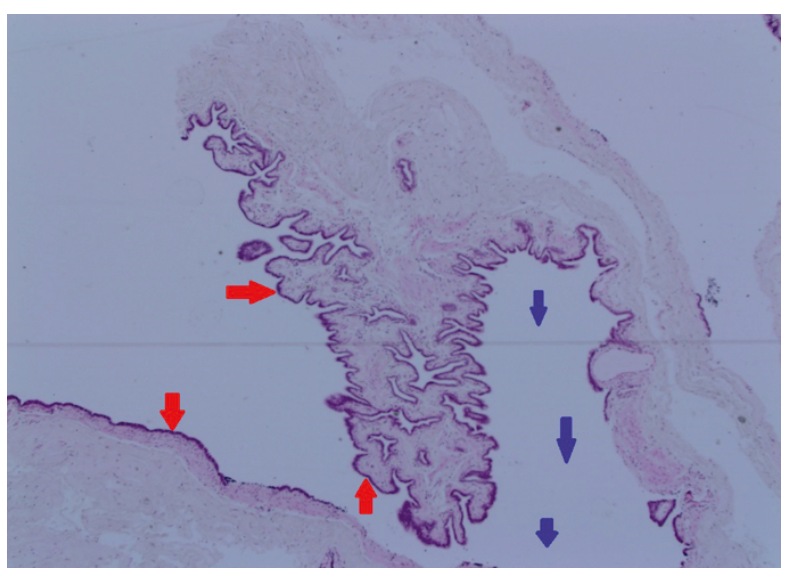

Figure 1. Haemotoxylin and eosin $\times 4$, stained section of cyst of Hattori shows cystic spaces (blue arrows) with slightly fibrotic walls lined by ciliated columnar epithelium (red arrows)

in absence of the uterus and variable degrees of vaginal hypoplasia or agenesis [8]. Other theories include the notion that Müllerian cysts of Hattori may represent metaplastic changes of the mesothelium into ciliated epithelium [7].

\section{Clinical presentation}

The most common sites of Müllerian cysts are within the pelvis [9], however, they can also be found, albeit less frequently, on the skin [10], the retroperitoneum or the mediastinum [11, 12]. Mediastinal cysts may present with chest symptoms, whereas abdominal cysts may present as an acute abdomen [13]. Mediastinal manifestations include cough $(22 \%)[2,9,14,15]$ chest pain (17\%) [9, 16-18], shortness of breath [18], dysphagia [9], and arm numbness [18] (Table 1). However, amongst the 40 reported cases of $\mathrm{COH}$, $55 \%$ were asymptomatic and detected as an incidental finding on imaging.

It is suggested that mediastinal cysts may account for up to $12-30 \%$ of mediastinal masses $[19,20]$ and Thomas-de-Montpréville at the Marie-Lannelong Surgical Centre in France, found that of a series of 163 cases of operated mediastinal non-malignant cysts, $\mathrm{COH}$ represented 5.5\% of cases [21].

All reviewed cases of $\mathrm{COH}$ in literature are found in the female population, often amongst those with high body mass indexes, and in some instances associated with gynaecological pathology $[3,5,9,21,22]$. The presence of aromatase in fatty tissue may result in high levels of oestrogen, which could be a contributory factor in the development of $\mathrm{COH}$ [23]. Moreover, a possible association between $\mathrm{COH}$ and the use of hormone replacement therapy (HRT) has been reported in two cases $[3,5,24]$. Similarly to that of the female population, Müllerian cysts in men typically develop in the pelvis [25].

\section{Imaging}

Cyst of Hatorri are often incidental findings of chest imaging [3, 5, 26-28]. Age of presentation are predominantly amongst woman between 40 to 60 years [22]. They are typically found between T3-T8 vertebrae [15] (Tables 1, 2); commonly occurring as a solitary cyst. However, multiple cysts have also been reported [2]. Imaging may detect an abnormality in a chest X-ray [18, 22], but computed tomography [24, 15, 17, 27] (Figure 2) or magnetic resonance imaging are recommended for detailed evaluation [15, 27] (Figure 3).

\section{Histology}

Histologically, Müllerian cysts are lined with ciliated columnar/tubal epithelium, surrounded by a thin smooth muscular layer without atypia or mitosis. Whilst this is identical to the histology of the fallopian tube (Figure 1), differential diagnoses should include mesothelial, gastro-enteric, thoracic duct or pericardial cysts $[5,9$, 26] (Table 3).

\section{Immunohistochemistry}

The immunohistochemistry of $\mathrm{COH}$ shows positive expression for oestrogen (Figure 4) and progesterone receptors (Figure 5) [2, 11, 14, 15, $21,22,24]$. The hormone receptor expression in the cyst wall, as well as the histological similarity to fallopian tube, supports the theory of its origin being remnants of embryonic Müllerian tissue [26]. This is further reinforced by the fact that the immunohistochemical profile of retroperitoneal Mullerian cysts are indistinguishable from that of the paravertebral mediastinal cysts [11]. Furthermore, all known reported cases in literature have been found within the female population $[2,3,4,9,11,15$, $16,18,19,21,22,24,26,28]$.

Cytokeratin 7 (CK7) is type II keratin of simple non-keratinizing epithelia which is present in uterine tubal epithelium as well as $\mathrm{COH}[11,22,27]$. It has shown expression in our case, however, CK7 is not a specific marker as it has shown positivity in carcinoid [29] as well. Furthermore, pan-Cytokeratins (CK AE1/ AE3) has also been detected in the $\mathrm{COH}[20,24]$. 
Table 1. Müllerian cyst of Hattori presentation, size and hormonal status in $\mathbf{4 0}$ cases reported in literature

\begin{tabular}{|c|c|c|c|c|c|c|c|c|}
\hline Author/year & Age/sex & Clinical symptoms & $\begin{array}{c}\text { Paravertebral } \\
\text { level }\end{array}$ & Diameter & ER/PR & CK7 & WT1 & $\begin{array}{c}\text { Paired } \\
\text { Box Gene } \\
8 \text { (PAX8) }\end{array}$ \\
\hline \multirow[t]{3}{*}{ Hattori 2005} & $52 / F$ & Persistent cough & Right T6 & $2.5 \mathrm{~cm}$ & $+/+$ & & & \\
\hline & $18 / F$ & Incidental & Right T5 & $2.0 \mathrm{~cm}$ & $+/+$ & & & \\
\hline & $49 / F$ & Cough & Left T4 & $2.0 \mathrm{~cm}$ & $+/+$ & & & \\
\hline \multirow{9}{*}{$\begin{array}{l}\text { Thomas-de-Montepreville } \\
2007\end{array}$} & $40 / F$ & Chest pain & Left T4 & $1.5 \mathrm{~cm}$ & $+/+$ & & & \\
\hline & $46 / F$ & Cough & Left T4 & $3.3 \mathrm{~cm}$ & $+/+$ & & & \\
\hline & $47 / F$ & Cough & Right T4/5 & $5.0 \mathrm{~cm}$ & $+/+$ & & & \\
\hline & $48 / F$ & Incidental & Left T5 & $3.0 \mathrm{~cm}$ & $+/+$ & & & \\
\hline & $50 / F$ & Chest pain & Right T3/4 & $3.2 \mathrm{~cm}$ & $+/+$ & & & \\
\hline & $51 / F$ & Incidental & Left T3/4 & $3.0 \mathrm{~cm}$ & $+/+$ & & & \\
\hline & $56 / F$ & Incidental & Left T8 & $1.3 \mathrm{~cm}$ & $-/+$ & & & \\
\hline & $58 / F$ & Cough & Pre-vertebral T5 & $4.5 \mathrm{~cm}$ & $-/$ & & & \\
\hline & $59 / F$ & Chest pain & Right T2-4 & $2.5 \mathrm{~cm}$ & $-/$ & & & \\
\hline Businger 2007 & $54 / F$ & Incidental & Left T4-6 & $4.5 \mathrm{~cm}$ & $+/+$ & & & \\
\hline Batt 2010 & $41 / \mathrm{F}$ & Chest pain & Left T6 & $2.1 \mathrm{~cm}$ & $+/+$ & & & \\
\hline Kobayashi 2012 & $53 / F$ & Incidental & Right T5 & $2.0 \mathrm{~cm}$ & $+/+$ & & & \\
\hline Liao 2012 & $48 / F$ & Chest tightness & Right T7 & $5.1 \mathrm{~cm}$ & $+/+$ & & & \\
\hline \multirow[t]{2}{*}{ Simmons 2013} & $52 / F$ & Shortness of breath & Pre-vertebral T4 & $4.1 \mathrm{~cm}$ & $+/+$ & & & \\
\hline & $47 / F$ & Incidental & $\mathrm{N} / \mathrm{A}$ & $5.0 \mathrm{~cm}$ & $+/$ & & & \\
\hline Lee 2014 & $42 / F$ & Incidental & Right T6 & $2.6 \mathrm{~cm}$ & $+/+$ & & & \\
\hline Miyawaki 2014 & $51 / F$ & Incidental & Left T5/6 & $4.0 \mathrm{~cm}$ & $+/+$ & & & \\
\hline Takahashi 2014 & $47 / f$ & Incidental & Right T4/5 & $2.0 \mathrm{~cm}$ & $+/+$ & + & & \\
\hline Chon 2015 & $51 / F$ & Chest pain & Left T6 & $3.0 \mathrm{~cm}$ & $+/+$ & & & \\
\hline Dakak 2015 & $51 / F$ & Dysphagia & Pre-vertebral T5 & $2.7 \mathrm{~cm}$ & $+/+$ & & & \\
\hline Skancke 2015 & $35 / F$ & Cough & Bilateral & $\begin{array}{l}8.0 \mathrm{~cm} \\
4.0 \mathrm{~cm}\end{array}$ & $+/+$ & & & \\
\hline Lochowski 2017 & $53 / F$ & Incidental & Right T4 & $3.0 \mathrm{~cm}$ & $+/+$ & & & \\
\hline Tsai 2017 & $44 / F$ & Incidental & Left T4 & $1.2 \mathrm{~cm}$ & $+/+$ & + & & \\
\hline Chandra 2017 & $52 / F$ & Chest pain/SOB & Left T3-5 & $3.9 \mathrm{~cm}$ & & & & \\
\hline Mowad 2017 & $49 / F$ & Cough & Left T4 & $3.6 \mathrm{~cm}$ & $+/+$ & + & + & + \\
\hline Karpathiou 2017 & $51 / F$ & Incidental & Left T4 & $3.0 \mathrm{~cm}$ & $+/+$ & + & + & \\
\hline \multirow[t]{2}{*}{ Oshima 2017} & $48 / F$ & Incidental & Left T4-5 & $3.1 \mathrm{~cm}$ & $+/+$ & & & \\
\hline & $40 / F$ & Incidental & Right T3-4 & $3.5 \mathrm{~cm}$ & $+/ ?$ & & & \\
\hline Lee 2018 & $22 / F$ & Incidental & Left T10 & $2.4 \mathrm{~cm}$ & $+/+$ & & + & \\
\hline Chao 2018 & $49 / F$ & Incidental & Right T5 & $1.3 \mathrm{~cm}$ & $+/+$ & + & & + \\
\hline \multirow[t]{4}{*}{ Miura 2018} & $50 / F$ & Cough & Left T6-7 & $1.9 \mathrm{~cm}$ & $+/+$ & & & \\
\hline & $52 / F$ & Incidental & Right T3-4 & $5.2 \mathrm{~cm}$ & $+/+$ & & & \\
\hline & $46 / F$ & Incidental & Right T4-5 & $4.1 \mathrm{~cm}$ & $+/+$ & & & \\
\hline & $52 / F$ & Incidental & Left T1-2 & $3 \mathrm{~cm}$ & $+/+$ & & & \\
\hline Sekimura 2018 & $40 / F$ & Incidental & Left & $1.2 \mathrm{~cm}$ & $+/+$ & & & + \\
\hline Idaewor 2018 & $56 / F$ & Cough & Left T3-4 & $3 \mathrm{~cm}$ & $+/+$ & & & \\
\hline Adachi 2018 & $53 / F$ & Incidental & Right T5 & $3 \mathrm{~cm}$ & $+/+$ & & & + \\
\hline Yasukawa 2018 & $41 / F$ & Incidental & Pre-vertebral T10 & $3 \mathrm{~cm}$ & $+/+$ & + & & + \\
\hline
\end{tabular}


Table 2. Clinical picture in the $40 \mathrm{COH}$ reported cases

\begin{tabular}{|c|c|}
\hline Clinical characteristics & $N=40$ \\
\hline Age & Average (18-59) \\
\hline $\begin{array}{c}\text { Sex } \\
F \\
M\end{array}$ & $\begin{array}{c}40 \\
0\end{array}$ \\
\hline Size $(\mathrm{cm})$ & Average (1.2-8.0) \\
\hline $\begin{array}{l}\text { Lateralisation } \\
\text { Right } \\
\text { Left } \\
\text { Pre-vertebral } \\
\text { Bilateral } \\
\text { N/A }\end{array}$ & $\begin{array}{c}15 \\
20 \\
3 \\
1 \\
1\end{array}$ \\
\hline $\begin{array}{l}\text { Vertebral level } \\
\text { T2 } \\
\text { T3 } \\
\text { T4 } \\
\text { T5 } \\
\text { T6 } \\
\text { T7 } \\
\text { T8 } \\
\text { T9 } \\
\text { T10 } \\
\text { Multiple } \\
\text { N/A }\end{array}$ & $\begin{array}{c}1 \\
5 \\
12 \\
8 \\
5 \\
1 \\
1 \\
0 \\
1 \\
3 \\
3\end{array}$ \\
\hline $\begin{array}{l}\text { Symptoms } \\
\text { Asymptomatic } \\
\text { Cough } \\
\text { Shortness of breath } \\
\text { Chest pain } \\
\text { Dysphagia }\end{array}$ & $\begin{array}{c}22 \\
9 \\
1 \\
7 \\
1\end{array}$ \\
\hline $\begin{array}{l}\text { Immunohistochemistry } \\
\text { ER+ } \\
\text { ER- } \\
\text { ER N/A } \\
\text { PR+ } \\
\text { PR- } \\
\text { PR N/A } \\
\text { PAX8+ } \\
\text { PAX8 N/A }\end{array}$ & $\begin{array}{c}36 \\
3 \\
1 \\
35 \\
2 \\
3 \\
4 \\
36\end{array}$ \\
\hline
\end{tabular}

ER - oestrogen receptors; PR - progesterone receptors; PAX8 — paired box gene 8
Wilms' tumor protein 1 (WT1) is transcriptional regulator protein that is thought to inhibit transcription of growth promoting genes. This protein is expressed in tissue of the fallopian tube as well as the Müllerian system [30] and in $\mathrm{COH}[2,15]$.

Paired box gene 8 (PAX-8); a gene found at 2 p13, is associated with tumours of thyroid gland, kidney/upper urinary tract and Müllerian system $[30,31]$ and is positive in $\mathrm{COH}[2$, 15, 22, 25, 27]. Cancer antigen 125 (CA-125), a protein encoded by MUC16 gene, is used as a tumour marker with a $79 \%$ sensitive for ovarian cancer. As it is present in amnion, coelomic and Müllerian epithelium [32-34], it has been found to be useful in the diagnosis of $\mathrm{COH}[2,11]$ (Figure 6). Cytokeratin 5/6, specific for mesothelial differentiation and usually positive in squamous epithelia, myoepithelial cells, and mesothelial cells, are negative in $\mathrm{COH}[21]$.

Cytokeratin 20(CK20), an epithelial marker often used to distinguish colon carcinoma (80\% are CK20+) [35], shows positivity in Merkel cell carcinoma and is positive only in some cases of extra-pulmonary small cell lung carcinoma [29]. Müllerian cysts show immunonegativity for CK $20[11,36]$.

Calretinin, a calcium binding protein, is positive in epithelioid pleural mesothelioma [40] but is negative in $\mathrm{COH}[7,11,22,27]$ (Figure 7).

Thyroid transcription factor (TTF-1), also called thyroid specific enhancer binding protein, distinguishes primary lung (TTF1+) from metastatic (usually TTF1-) lung carcinoma [37]; it is negative in Müllerian cysts [15, 17, 19].

BerEP4 marker, also known as epithelial cell adhesion molecule, is an antibody to cell
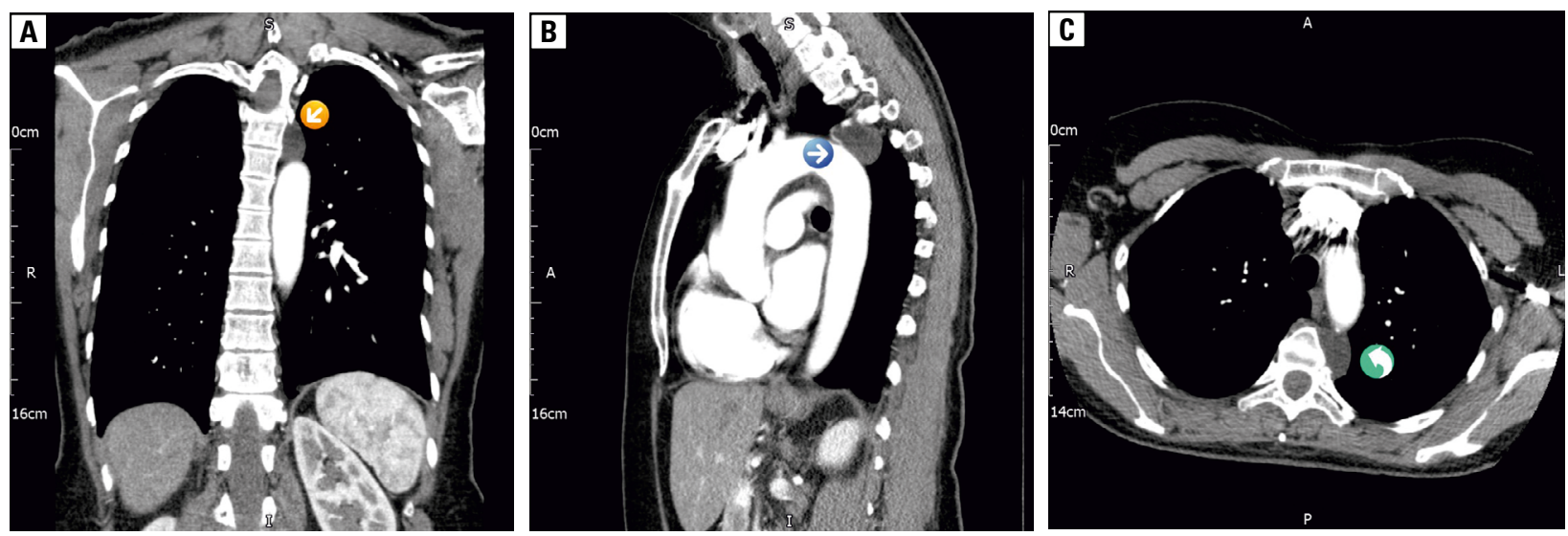

Figure 2. A. Chest computed tomography (CT) coronal view; soft tissue mass at the level of aortic arch (orange arrow); B. CT chest-sagittal view; soft tissue mass at the level of aortic arch (blue arrow); C. CT chest-axial view; soft tissue mass at the level of aortic arch (green arrow) 

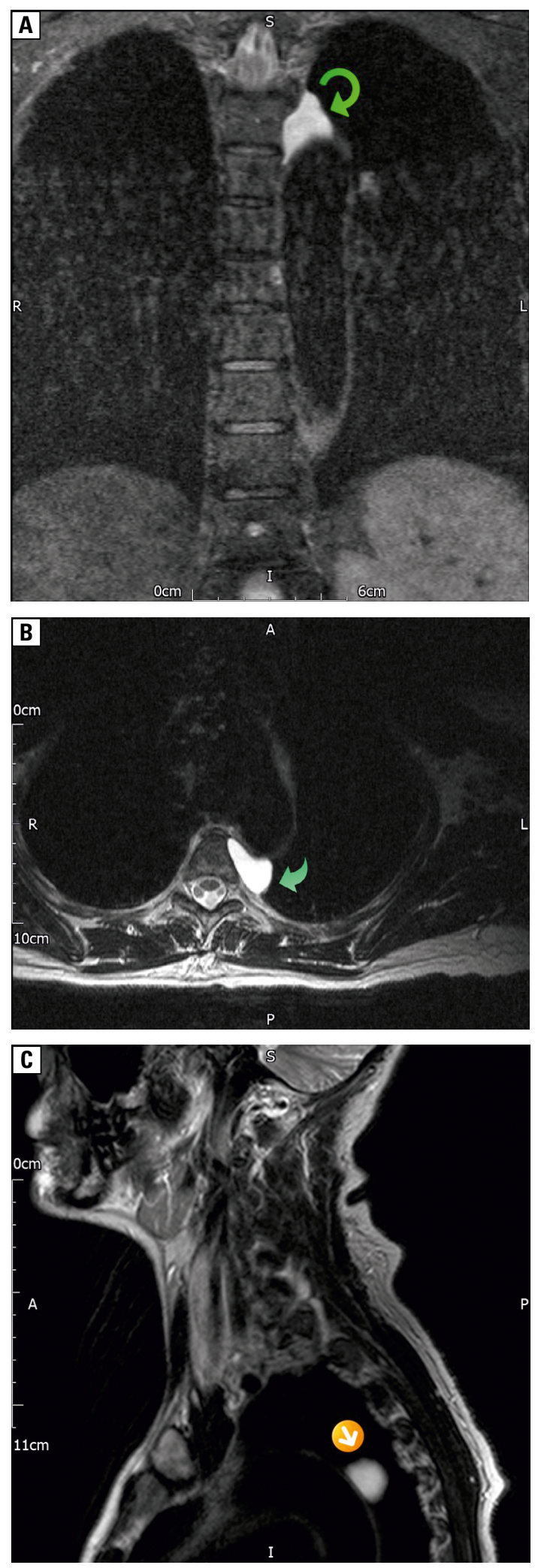

Figure 3. A. Magnetic resonance image (MRI) chest-coronal view; left paravertebral mass of cystic nature seen very close to the aortic arch (green arrow); B. MRI chest-axial view; left paravertebral mass of cystic nature seen very close to the aortic arch (green arrow); C. MRI chest-sagittal view; left paravertebral mass of cystic nature seen very close to the aortic arch (orange arrow)
Table 3. Histopathology of the mediastinal cysts $[5,9,14,39,41]$

\begin{tabular}{|c|c|}
\hline Origin & Histology \\
\hline Mullarian (Hattori) & $\begin{array}{l}\text { Ciliated columnar/tubal apocrine-like secre- } \\
\text { tory cells, surrounded by smooth muscles. } \\
\text { They are Oestrogen Receptor and proge- } \\
\text { sterone receptor positive (ER }+/ P R+)\end{array}$ \\
\hline Bronchogenic & $\begin{array}{l}\text { Pseudostratified, ciliated columnar } \\
\text { epithelium, smooth muscles, cartilage } \\
\text { and bronchial gland }\end{array}$ \\
\hline Enterogenous & Gastrointestinal mucosa \\
\hline Mesothelial & $\begin{array}{l}\text { Single-cell layer of mesothelial cells sur- } \\
\text { rounded by external fibrous capsule }\end{array}$ \\
\hline Neurenteric & Enteric and neural tissue \\
\hline Pericardial cysts & Single layer of mesothelial cells \\
\hline Thoracic duct cysts & Lymphatic duct lining \\
\hline Thymic cyst & $\begin{array}{l}\text { Flattened cuboidal epithelium and Has- } \\
\text { sal's corpuscles }\end{array}$ \\
\hline Hydatid cyst & $\begin{array}{l}\text { Germinal layer with nucleoli . Protosco- } \\
\text { lices with double row hooklets round } \\
\text { suckers that comprise "hydatid sand". } \\
\text { Daughter cysts }\end{array}$ \\
\hline
\end{tabular}

ER — oestrogen receptors; PR — progesterone receptors

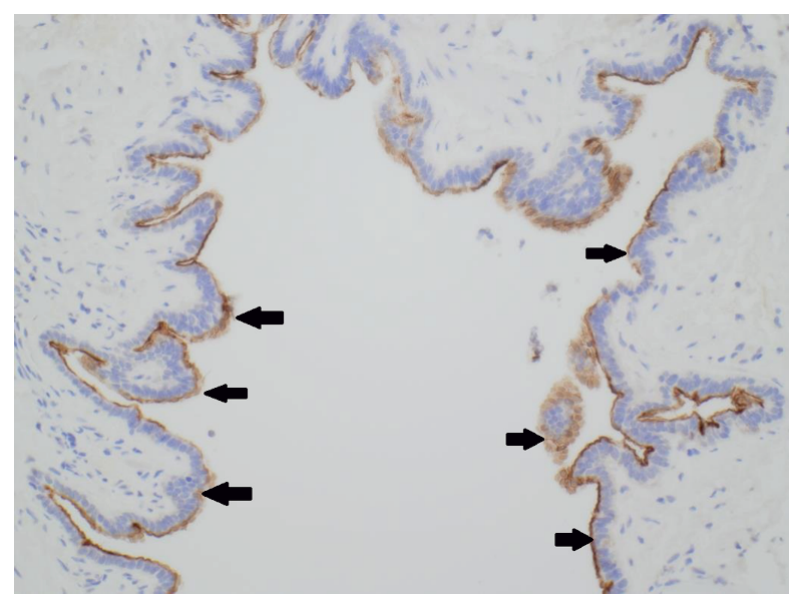

Figure 4. $\times 10$, the lining epithelial cells are strongly positive for oestrogen receptors (arrows)

membrane glycoprotein expressed on healthy epithelia and in various carcinomas. This marker is reported to be negative in mesotheliomas [38]. Conversely, BerEP4 is reported to be positive in $\mathrm{COH}$ [7] (Figure 8).

Thrombomodulin, a transmembrane glycoprotein and cofactor for the thrombin-mediated activation of protein $\mathrm{C}$, has a $95 \%$ specificity and $65 \%$ sensitivity to mesothelioma [39]. This marker is negative in $\mathrm{COH}$ [7] (Figure 9). 


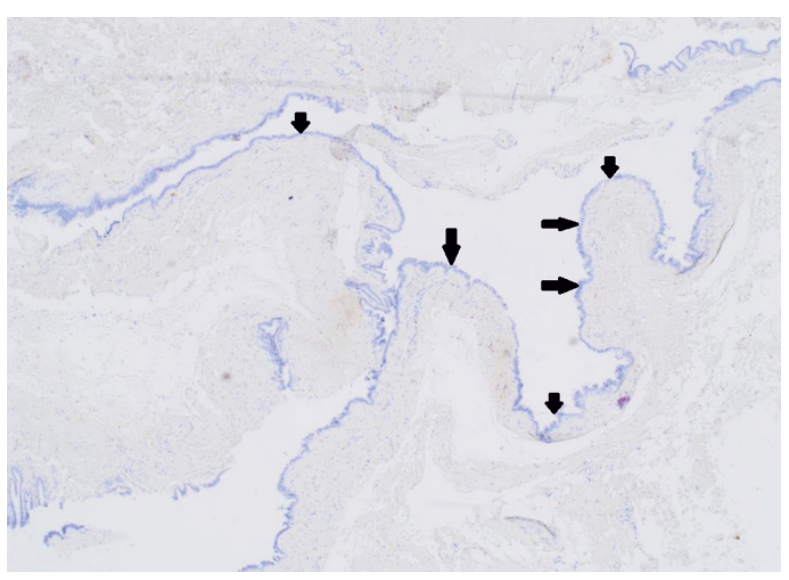

Figure 5. $\times 10$, the cells are also strongly positive for progesterone receptors (arrows)

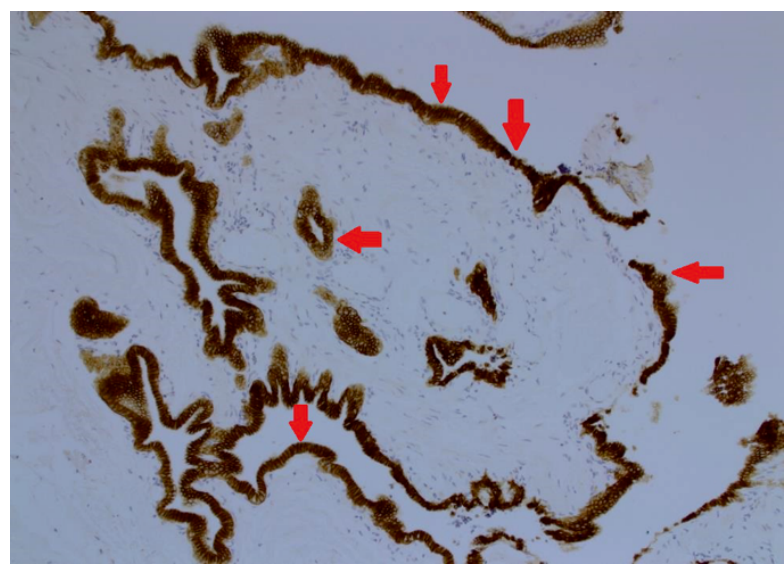

Figure 6. $\times 10$, there is weak luminal staining of the epithelial cell with cancer antigen 125

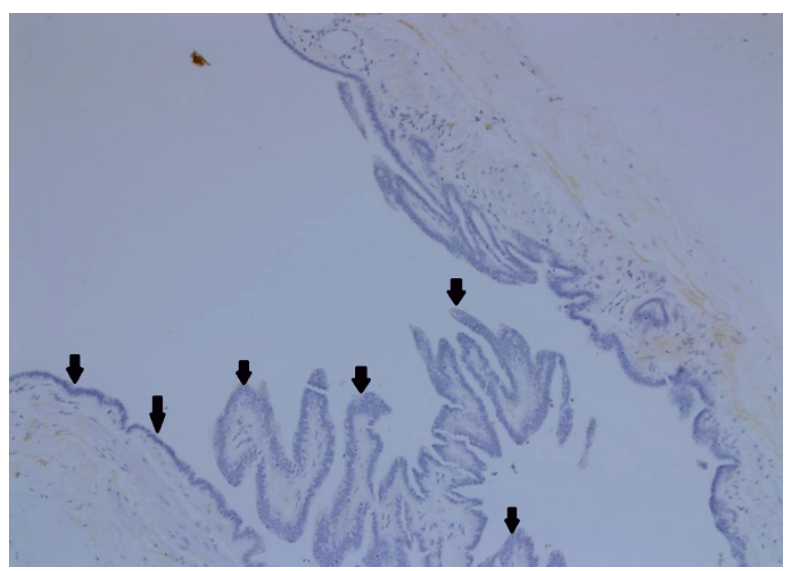

Figure 7. $\times 10$, the epithelial cells are negative for Calretinin (arrows)

\section{Differential diagnosis}

Generally, mediastinal cysts are rare; they can be either acquired or congenital and their origins

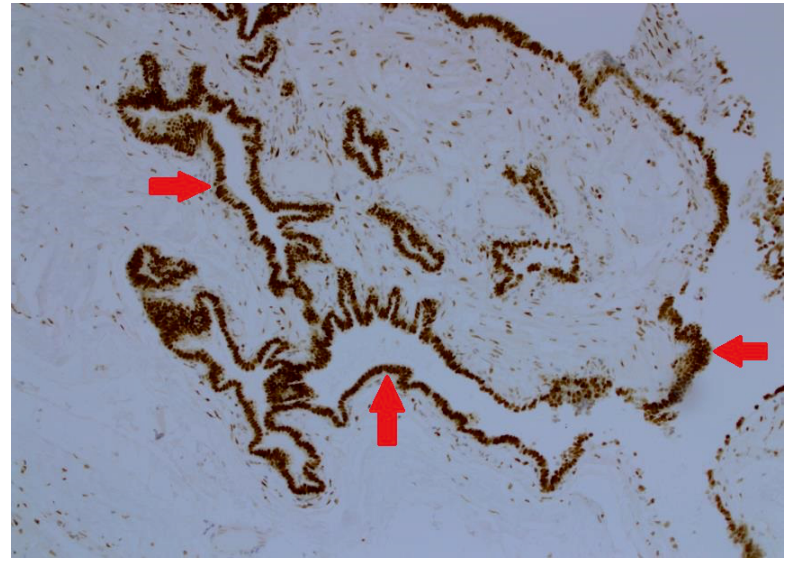

Figure 8. $\times 10$, the epithelial cells are strongly positive for BerEP4 (arrows)

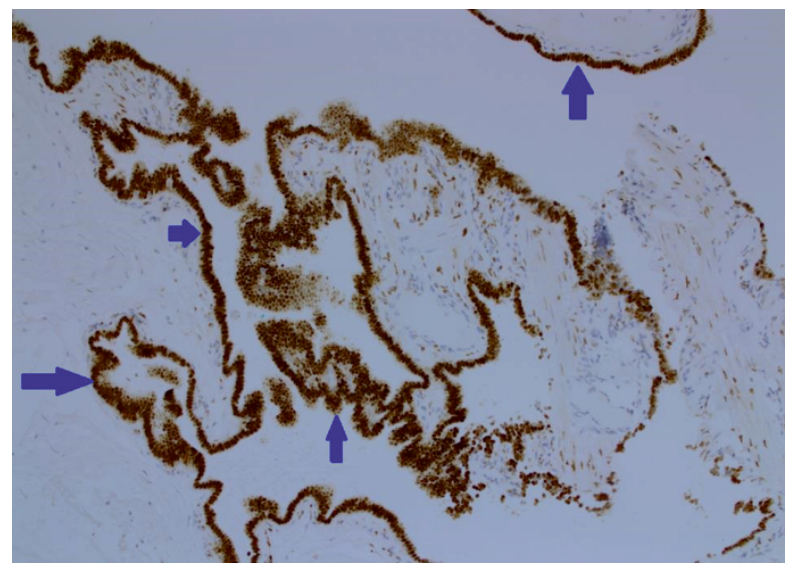

Figure 9. $\times 10$, the epithelia cells are negative for Thrombomodulin (arrows)

may be of Müllerian, thymic [40], pericardial, bronchogenic or neuroenteric tissue. They may also represent oesophageal duplication [18, 28]. Other differential diagnoses may include mesothelial, gastro-enteric, thoracic duct cysts [26] or due hydatid disease [41] (Table 3). Anterior spinal meningocele containing cerebrospinal fluid, located in the posterior mediastinum, may appear as a cystic lesion, however, a meningocele will communicate with the spinal canal unlike a true cyst [3].

\section{Treatment}

The long-term prognosis of Müllerian cysts is unclear. However, the risk of malignant transformation must not be discounted. The evidence suggests that presence of embryonic tissue away from its typical site, may give rise to malignant transformation. For example, cryptorchidism 
within the male population significantly increases the risk of developing testicular cancer. Furthermore, patients with mediastinal goitres are more susceptible to thyroid cancer. Surgical excision is advisable to ensure formal analysis and diagnosis, symptomatic relief and elimination of possible malignant transformation of the Müllerian tissue $[18,42]$. Surgical approaches taken include open thoracotomy $[7,9]$ or video-assisted thoracoscopic surgery (VATS) [3, 15, 25, 27, 43-45].

\section{Conclusion}

Of all reviewed cases in literature, $\mathrm{COH}$ are found with the female population; often amongst those with high BMI's and in conjunction with gynaecological pathology. Histological appearance shows ciliated columnar epithelium surrounded by a smooth muscular layer, identical to the histology of the fallopian tube, supporting the theory of probable Müllerian origin. Surgical excision of such cysts are the treatment of choice as this allows for definitive diagnosis, symptomatic relief and a reduced risk of malignant transformation of Müllerian tissue.

\section{Acknowledgment}

Authors would like to thank Ms Sarah Colquhoun, Senior Library Assistant at Basildon Healthcare Library at Basildon University Hospital for her valuable assistance in collecting the scientific reference papers.

\section{Conflict of interest}

None declared.

\section{References:}

1. Ludwig KS. The Mayer-Rokitansky-Küster syndrome. An analysis of its morphology and embryology. Part II: Embryology. Arch Gynecol Obstet. 1998; 262(1-2): 27-42, doi: 10.1007/ s004040050225, indexed in Pubmed: 9835998.

2. Skancke MD, Auzenne TD, Tabbara SO, et al. Thoracoscopic resection of multiple Müllerian cysts. Ann Thorac Surg. 2015; 100(5): 1898-1900, doi: 10.1016/j.athoracsur.2015.01.076, indexed in Pubmed: 26522538.

3. Chao C, Vanguri V, Uy K. Robot-Assisted thoracoscopic resection of a posterior mediastinal Mullerian cyst. Case Rep Pulmonol. 2018; 2018: 1424275, doi: 10.1155/2018/1424275, indexed in Pubmed: 29535882.

4. Chao C, Vanguri V, Uy K. Robot-Assisted thoracoscopic resection of a posterior mediastinal Mullerian cyst. Case Reports in Pulmonology. 2018; 2018: 1-4, doi: 10.1155/2018/1424275.

5. Hattori H. Ciliated cyst of probable mullerian origin arising in the posterior mediastinum. Virchows Arch. 2005; 446(1): 82-84, doi: 10.1007/s00428-004-1087-0, indexed in Pubmed: 15480767.

6. Kobayashi S, Inoue T, Karube Y, et al. A case of Mullerian cyst arising in posterior mediastinum. Ann Thorac Cardiovasc Surg. 2012; 18(1): 39-41, doi: 10.5761/atcs.cr.11.01678, indexed in Pubmed: 21881341.
7. Coppens L, Bonnet P, Andrianne R, et al. Adult müllerian duct or utricle cyst: clinical significance and therapeutic management of 65 cases. J Urol. 2002; 167(4): 1740-1744, indexed in Pubmed: 11912400

8. Idaewor P, Al-Zawi ASA, Ozua P, et al. Benign paravertebral cyst of Hattori: A case report and review of literature. Medical Research Journal. 2018; 3(2): 102-107, doi: 10.5603/ mrj.2018.0017.

9. Morcel K, Camborieux L, Guerrier D. Programme de Recherches sur les Aplasies Müllériennes. Mayer-Rokitansky-Küster-Hauser (MRKH) syndrome. Orphanet J Rare Dis. 2007; 2: 13, doi: 10.1186/1750-1172-2-13, indexed in Pubmed: 17359527.

10. Dakak M. An unusual cyst of posterior mediastinum: Mullerian cyst. Turkish Journal of Thoracic and Cardiovascular Surgery. 2015: 154-156, doi: 10.5606/tgkdc.dergisi.2015.7670.

11. Torisu-Itakura H, Itakura E, Horiuchi R, et al. Cutaneous ciliated cyst on the leg in a woman of menopausal age. Acta Derm Venereol. 2009; 89(3): 323-324, doi: 10.2340/00015555-0626, indexed in Pubmed: 19479143.

12. Konishi E, Nakashima Y, Iwasaki T. Immunohistochemical analysis of retroperitoneal Müllerian cyst. Hum Pathol. 2003; 34(2): 194-198, doi: 10.1053/hupa.2003.12, indexed in Pubmed: 12612890 .

13. Chong SJ, Kim SY, Kim HS, et al. Cutaneous ciliated cyst in a 16-year-old girl. J Am Acad Dermatol. 2007; 56(1): 159-160, doi: 10.1016/j.jaad.2006.08.005, indexed in Pubmed: 17097367.

14. Mohammed M, Allen-Proctor M, Wojtowycz A. Müllerian remnant cyst as a cause of acute abdomen in a female patient with Müllerian agenesis: radiologic and pathologic findings. Case Rep Radiol. 2016; 2016: 6581387, doi: 10.1155/2016/6581387, indexed in Pubmed: 27446624.

15. Hattori H. High prevalence of estrogen and progesterone receptor expression in mediastinal cysts situated in the posterior mediastinum. Chest. 2005; 128(5): 3388-3390, doi: 10.1378/ chest.128.5.3388, indexed in Pubmed: 16304289.

16. Simmons M, Duckworth LV, Scherer K, et al. Mullerian cysts of the posterior mediastinum: report of two cases and review of the literature. J Thorac Dis. 2013; 5(1): E8-EE10, doi: 10.3978/j. issn.2072-1439.2012.07.10, indexed in Pubmed: 23372963.

17. Batt RE, Mhawech-Fauceglia P, Odunsi K, et al. Pathogenesis of mediastinal paravertebral müllerian cysts of Hattori: developmental endosalpingiosis-müllerianosis. Int J Gynecol Pathol. 2010; 29(6): 546-551, doi: 10.1097/PGP.0b013e3181e3640a, indexed in Pubmed: 20881858.

18. Chon SH, Im UiJ, Song DS. Paravertebral mediastinal Mullerian cyst resected by video assisted thoracoscopic surgery. J Thorac Dis. 2015; 7(3): E47-E49, doi: 10.3978/j.issn.20721439.2014.12.05, indexed in Pubmed: 25922749.

19. Chandra N, Seevanayagam S. A case of posterior mediastinal cyst of Mullerian type (Hattori's cysts). Heart, Lung and Circulation. 2017; 26: S360-S361, doi: 10.1016/j.hlc.2017.03.024.

20. Lee JE, Cha YKi, Kim JS, et al. Müllerian cyst in posterior mediastinum in a young woman. Balkan Med J. 2018; 35(2): 216-218, doi: 10.4274/balkanmedj.2017.0896, indexed in Pubmed: 29180343.

21. Liao TC, Chang FP, Chou TY, et al. Pregressive enlarging symptomatic mediastinal mullerian cyst in a female patient with high essential estradio level. J Radiol Sci. 2012; 37: 117-121.

22. Thomas-de-Montpréville V, Dulmet E. Cysts of the posterior mediastinum showing müllerian differentiation (Hattori's cysts). Ann Diagn Pathol. 2007; 11(6): 417-420, doi: 10.1016/j.anndiagpath.2006.12.011, indexed in Pubmed: 18022126.

23. Tsai PC, Yeh YC, Hsu PK, et al. Posterior mediastinal paravertebral Mullerian cyst resected by uniportal video-assisted thoracoscopic surgery: case report and review of literature. Journal of Thoracic Disease. 2017; 9(S14): AB032-AB032, doi: 10.21037/jtd.2017.s032.

24. Miura H, Miura J, Hirano H. Mediastinal cysts with Mullerian differentiation. Respirol Case Rep. 2018; 6(5): e00324, doi: 10.1002/rcr2.324, indexed in Pubmed: 29750109.

25. Łochowski M, Kuncman W, Rębowski M, et al. A case of Mullerian cyst resected by video assisted thoracoscopic surgery. Video-Assisted Thoracic Surgery. 2017; 2: 31-31, doi: 10.21037/ 
vats.2017.05.03.

26. Sekimura A, Iwai S, Funasaki A, et al. Müllerian cyst in posterior mediastinum: A report of a case. Int J Surg Case Rep. 2018; 49: 163-165, doi: 10.1016/j.ijscr.2018.06.037, indexed in Pubmed: 30015213.

27. Hattori H. High prevalence of estrogen and progesterone receptor expression in mediastinal cysts situated in the posterior mediastinum. Chest. 2005; 128(5): 3388-3390, doi: 10.1378/ chest.128.5.3388, indexed in Pubmed: 16304289.

28. Lee S, Hwang C, Park D, et al. A ciliated cyst with Müllerian differentiation arising in the posterior mediastinum. The Korean Journal of Pathology. 2014; 48(5): 401-404, doi: 10.4132/ koreanjpathol.2014.48.5.401.

29. Businger AP, Frick H, Sailer M, et al. A ciliated cyst in the posterior mediastinum compatible with a paravertebral Mullerian cyst. Eur J Cardiothorac Surg. 2008; 33(1): 133-136, doi: 10.1016/j.ejcts.2007.09.036, indexed in Pubmed: 17977003.

30. Al-Zawi ASA, Prodromou A, Chicken W, et al. Merkel cell carcinoma: literature review. Nowotwory. Journal of Oncology. 2017; 67(2): 127-131, doi: 10.5603/njo.2017.0020.

31. Fabien-Dupuis C, Cooper B, Upperman J, et al. Mullerian-type ciliated cyst of the thigh with PAX-8 and WT1 positivity: a case report and review of the literature. Case Rep Med. 2016; 2016: 2487820, doi: 10.1155/2016/2487820, indexed in Pubmed: 28070193.

32. Ozcan A, Liles N, Coffey D, et al. PAX2 and PAX8 expression in primary and metastatic müllerian epithelial tumors: a comprehensive comparison. Am J Surg Pathol. 2011; 35(12): 1837-1847, doi: 10.1097/PAS.0b013e31822d787c, indexed in Pubmed: 21989345.

33. Nanbu Y, Fujii S, Konishi I, et al. Immunohistochemical localization of CA130 in fetal tissues, and in normal and neoplastic tissues of the female genital tract. Asia Oceania J Obstet Gynaecol. 1990; 16(4): 379-387, doi: 10.1111/j.1447-0756.1990. tb00365.x, indexed in Pubmed: 2099733.

34. Scharl A, Crombach G, Vierbuchen M, et al. CA 125 in normal tissues and carcinomas of the uterine cervix, endometrium and fallopian tube. I. Immunohistochemical detection. Arch Gynecol Obstet. 1989; 244(2): 103-112, doi: 10.1007/bf00931381, indexed in Pubmed: 2712596.

35. Puls LE, Davey DD, DePriest PD, et al. Immunohistochemical staining for CA-125 in fallopian tube carcinomas. Gynecol Oncol. 1993; 48(3): 360-363, doi: 10.1006/gyno.1993.1063, indexed in Pubmed: 8462903.

36. Owens CL, Epstein JI, Netto GJ. Distinguishing prostatic from colorectal adenocarcinoma on biopsy samples: the role of morphology and immunohistochemistry. Arch Pathol Lab Med. 2007; 131(4): 599-603, doi: 10.1043/1543-2165(2007)131[599:DPFCAO]2.0.CO;2, indexed in Pubmed: 17425391.

37. Madakshira M, Singh V. A curious case of Mullerian origin retroperitoneal cyst. Journal of Case Reports. 2016: 331-333, doi: 10.17659/01.2016.0081.

38. Pelosi G, Fraggetta F, Pasini F, et al. Immunoreactivity for thyroid transcription factor-1 in stage I non-small cell carcinomas of the lung. Am J Surg Pathol. 2001; 25(3): 363-372, doi: 10.1097/00000478200103000-00011, indexed in Pubmed: 11224607.

39. Carella R. mmunohistochemical Panels For Differentiating Epithelial Malignant Mesothelioma From Lung Adenocarcinoma: A Study With Logistic Regression Analysis. The American Journal of Surgical Pathology. 2001; 25(1): 43-50.

40. Ordóñez NG. Immunohistochemical diagnosis of epithelioid mesotheliomas: a critical review of old markers, new markers. Hum Pathol. 2002; 33(10): 953-967, doi: 10.1053/ hupa.2002.128248, indexed in Pubmed: 12395367.

41. Sameh IS, Ismaeil MF, Nasser MA, et al. Huge cervico-thoracic thymic cyst. Interact Cardiovasc Thorac Surg. 2003; 2(3): 339-340, doi: 10.1016/S1569-9293(03)00077-X, indexed in Pubmed: 17670062.

42. Msougar Y, Afandi O, Ihfa N, et al. Mediastinal hydatid cyst: a case report. J Med Case Rep. 2013; 7: 236, doi: 10.1186/17521947-7-236, indexed in Pubmed: 24099329.

43. Mowad R, Samra NS, Rao V. A Mullerian cyst resected from the posterior mediastinum. J La State Med Soc. 2017; 169(2): 43-47, indexed in Pubmed: 28414660.

44. Adachi M, Sano I, Hashimoto S, et al. A case of Mullerian cyst arising in the posterior mediastinum. The Journal of the Japanese Association for Chest Surgery. 2018; 32(6): 713-718, doi: 10.2995/jacsurg.32.713.

45. Takahashi Y, Omori H, Yoshifuku S, et al. A case of Müllerian cyst arising in the posterior mediastinum. Nihon Gekakei Rengo Gakkaishi (Journal of Japanese College of Surgeons). 2014; 39(4): 804-807, doi: 10.4030/jjcs.39.804.

46. Yasukawa M, Uchiyama T, Ohbayashi C, et al. A case of a Müllerian cyst arising in the posterior mediastinum. Oxf Med Case Reports. 2018; 2018(11): omy080, doi: 10.1093/omcr/omy080, indexed in Pubmed: 30319783. 